\title{
Correction: Lack of functional and expression homology between human and mouse aldo-keto reductase $1 C$ enzymes: implications for modelling human cancers
}

Pedro Veliça ${ }^{1}$, Nicholas J Davies ${ }^{1}$, Pedro P Rocha ${ }^{2,3}$, Heinrich Schrewe ${ }^{2,3}$, Jonathan P Ride ${ }^{1}$, Chris M Bunce ${ }^{1 *}$

\section{Correction}

It has come to our attention that since publication of our article [1], in the body of the article the term androstenedione has been used in error. The experiments in this study used androstanedione as a test substrate. Androstenedione was not used in any experiments. This error does not in any way invalidate the conclusion of the paper that aldo-keto reductases of the mouse and human $1 \mathrm{C}$-subfamilies lack functional and expression homology. The authors apologise for any confusion caused.

\begin{abstract}
Author details
${ }^{1}$ School of Biosciences, University of Birmingham, Edgbaston B15 2TT Birmingham, UK. Department of Developmental Genetics, Max-Planck Institute for Molecular Genetics, Ihnestrasse 73, 14195 Berlin, Germany. ${ }^{3}$ Institute of Medical Genetics, Charité-University Medicine, Berlin, Germany.

Received: 28 January 2010

Accepted: 28 January 2010 Published: 28 January 2010

\section{References}

1. Veliça P, Davies NJ, Rocha PP, Schrewe H, Ride JP, Bunce CM: Lack of functional and expression homology between human and mouse aldoketo reductase $1 \mathrm{C}$ enzymes: implications for modelling human cancers. Mol Cancer 2009, 8:121.
\end{abstract}

\footnotetext{
* Correspondence: c.m.bunce@bham.ac.uk

${ }^{1}$ School of Biosciences, University of Birmingham, Edgbaston B15 2TT
} Birmingham, UK

Publish with Biomed Central and every scientist can read your work free of charge

"BioMed Central will be the most significant development for disseminating the results of biomedical research in our lifetime. "

Sir Paul Nurse, Cancer Research UK

Your research papers will be:

- available free of charge to the entire biomedical community

- peer reviewed and published immediately upon acceptance

- cited in PubMed and archived on PubMed Central

- yours - you keep the copyright

Submit your manuscript here:

http://www.biomedcentral.com/info/publishing_adv.asp 